\title{
IMPROVEMENT OF LISTENING SKILL ON SHORT STORIES BY APPLYING MIND MAPPING
}

\author{
Intan Kustyarini, Hadi Mulyono, Fadhil Purnama Adi
}

Universitas Sebelas Maret

intan.kustyarini2@gmail.com

\section{Article History}

accepted 09/07/2018

approved 01/08/2018

published 17/09/2018

Keywords

listening skill, mind

mapping

\begin{abstract}
Based on the observation result the listening skill on short stories of students class $V$ of SDN Sigit II,Tangen, Sragen in academic 2017/2018 still low. Students experience problems on concentration and remember the contents of short stories. This research aims to:(1) apply Mind Mapping to improve listening skill on short stories, and (2) to describe the precise steps of Mind Mapping to improve listening skill on short stories. This research is clasroom action research (CAR) conducted during two cycles. Each cycles consists of four stages, there are planning, acting, observing, and reflecting. The subject of this research is fifth grade students of SDN Sigit II. Technique of data collecting used observation, interviews, and documentation. The validity technique used were content validity, triangualtion of techniques and triangulation of source. Technique of the data analysis used is interactive analysis. Result of this research indicate that listening skill on short stories of students class $V$ of SDN Sigit II from preaction until cycle II has increased by $86,6 \%$. The conclusion of this research are: (1) the implementation of Mind Mapping can improve the listening skill of short stories of fifth grade students at SDN Sigit II, and (2) discribed the precise step of Mind Mapping to improve listening skill on short stories.
\end{abstract}

Social, Humanities, and Education Studies (SHEs): Conference Series

p-ISSN 2620-9284 https://jurnal.uns.ac.id/shes 


\section{PENDAHULUAN}

Menyimak adalah aktivitas berbahasa pertama yang dikenal manusia sejak lahir, sebelum mulai belajar dan menguasai keterampilan berbahasa lain manusia akan mengenal menyimak terlebih dahulu. Hal ini senada dengan pendapat Ghazali (2013) yang mengatakan bahwa sampai sekarang beberapa praktisi masih berpendapat bahwa pembelajaran bahasa adalah sebuah proses yang berjalan linier/lurus, yaitu diawali dengan menguasai bahasa lisan (menyimak dan berbicara) dan baru kemudian beralih ke bahasa tulis (membaca dan menulis). Sejak di Sekolah Dasar (SD) siswa diajarkan dan dilatih tentang keempat keterampilan bahasa yang dimuat dalam mata pelajaan Bahasa Indonesia, keempat keterampilan itu termasuk keterampilan menyimak. Seperti yang kita ketahui bahwa pada praktiknya pembelajaran yang berlangsung di sekolah mengharuskan siswa untuk banyak melalukan aktivitas menyimak. Kegiatan tersebut seperti saat guru menjelaskan materi, saat guru menginstruksikan suatu langkah-langkah, saat guru menceritakan suatu cerita, dan sebagainya. Namun, begitu banyaknya porsi menyimak dalam keperluan pembelajaran di sekolah seringkali belum dibarengi dengan melatihnya keterampilan menyimak siswa secara maksimal.

Hal tersebut seperti yang dijelaskan oleh Field (Abidin, 2012) bahwa pembelajaran menyimak belum dianggap pelajaran penting dan oleh karennya banyak ditinggalkan para guru. ini menandakan bahwa praktik pembelajaran menyimak jarang terlaksanakan. Hal serupa juga biasa terjadi dalam pembelajaran menyimak cerita pendek. Seringkali guru enggan lisankan suatu cerita dan meminta siswa membaca sendiri cerita pada buku siswa atau guru sudah melisankan namun dengan cara guru membaca teks cerita sehingga kurang menjiwai isi cerita. Hal serupa juga terjadi di kelas V SD Negeri Sigit II tahun ajaran 2017/2018

Berdasarkan hasil wawancara dan observasi pada tanggal 25 Januari 2018 diperoleh data bahwa pada praktiknya guru sudah melisankan cerita, namun cerita tersebut juga ada pada buku siswa. Dari fakta tersebut ditemukanlah permasalahan rendahnya keterampilan menyimak cerita pendek siswa kelas V SD Negeri Sigit II tahun ajaran 2017/2018 masih rendah. Hasil pretest yang dilaksanakan pada tanggal 26 Januari 2018 memperkuat bukti bahwa terdapat permasalahan rendahnya hasil belajar siswa pada pokok bahasan menyimak cerita pendek. Dari 15 siswa hanya 2 siswa yang tuntas KKM dan masuk pada kategori terampil.

Salah satu upaya yang dapat dilakukan untuk meningkatkan keterampilan menyimak cerita pendek adalah dengan penerapan Mind Mapping. Edward (2009) mengatakan bahwa mind map menjadi cara mencatat/meringkas yang mengakomodir atau mengikuti cara kerja otak secara natural. Sedangkan Buzan (2010:4) mengemukakakn bahwa mind map adalah cara mencatat yang kreatif, efektif, dan secra harfiah akan "memetakan" pikiran-pikiran kita. Dengan diterapkannya Mind Mapping saat menyimak cerita, akan membuat aktivitas menyimak menjadi kegiatan yang aktif serta akan membantu siswa untuk mencatat dan mengingat isi cerita. Selain itu dengan penerapan Mind Mapping pembelajaran juga akan menjadi menyenangkan karena siswa akan berbain dengan berbagai warna dan gambar sesuai dengan kreasi mereka. Untuk menghindari perpecahan konsentrasi saat menyimak cerita maka perlu penerapan Mind Mapping harus dibarengi dengan langkah-langkah yang tepat.

Berdasarkan uraian tersebut, maka rumusan masalah dalam peneltian ini yaitu: (1) Apakah penerapan Mind Mapping yang peneliti terapkan dapat meningkatkan keterampilan menyimak cerita pendek pada siswa kelas V SD Negeri Sigit II tahun ajaran 2017/2018?; (2) Bagaimanakah langkah-langkah penerapan Mind Mapping 
yang tepat dalam meningkatkan keterampilan menyimak cerita pendek pada siswa kelas V SD Negeri Sigit II tahun ajaran 2017/2018?

Adapun tujuan dari penelitian ini adalah: (1) meningkatkan keterampilan menyimak cerita pendek pada siswa kelas V SD Negeri Sigit II tahun ajaran 2017/2018 melalui penerapan Mind Mapping; (2) mendeskripsikan langkah-langkah penerapan Mind Mapping yang tepat untuk meningkatkan keterampilan menyimak cerita pendek pada siswa kelas V SD Negeri Sigit II tahun ajaran 2017/2018.

\section{METODE}

Penelitian ini dilaksanakan pada siswa kelas V SD Negeri Sigit II tahun pelajaran 2017/2018 yang dilaksanakan pada semester genap. Data yang digunakan pada penelitian ini adalah data kualitatif dan data kuantitatif dengan sumber data primer yaitu data dari guru dan siswa, dan sumber data sekunder yaitu data dari silabus, rencana pelaksaan pembelajaran, sera dokumentasi-dokumentasi. Data dalam penelitian ini dikumpulkan dengan wawancara, observasi, tes, serta dokumentasi. Validitas data yang digunakan yaitu validitas isi, triangulasi sumber dan teknik. Teknik analisi data yang digunakan pada penelitian ini adalah model interaktif Milles dan Huberman. Indikator kinerja yang ditetapkan pada penelitian ini adalah $80 \%$ siswa terampil menyimak cerita pendek. Serta penelitian ini menggunakan prosedur penelitian yang dilakukan melalui 2 siklus. Setiap siklus terdiri dari empat tahap yaitu perencanaan, tindakan, observasi dan refleksi.

\section{HASIL DAN PEMBAHASAN}

Hasil belajar siswa dalam pembelajaran menyimak cerita pendek sebelum diterapkannya Mind Mapping dapat dilihat distribusi frekuensinya pada tabel $1 \mathrm{di}$ bawah ini:

Tabel 1. Distribusi frekuensi nilai menyimak cerita pendek pratindakan

\begin{tabular}{|c|c|c|c|c|c|}
\hline \multirow{2}{*}{$\begin{array}{c}\text { Interval } \\
\text { Nilai }\end{array}$} & \multirow{2}{*}{$\begin{array}{l}\text { Frekuensi } \\
\text { (fi) }\end{array}$} & \multirow{2}{*}{$\begin{array}{l}\text { Nilai Tengah } \\
\text { (xi) }\end{array}$} & \multirow[t]{2}{*}{ fi.xi } & \multicolumn{2}{|c|}{ Persentase } \\
\hline & & & & Relatif & Kumulatif \\
\hline $40-46$ & 6 & 43 & 258 & $40 \%$ & $40 \%$ \\
\hline $47-53$ & 5 & 50 & 250 & $33,33 \%$ & $73,33 \%$ \\
\hline $54-60$ & 2 & 57 & 114 & $13,33 \%$ & $86,66 \%$ \\
\hline $61-67$ & 0 & 64 & 0 & $0 \%$ & $86,66 \%$ \\
\hline $68-74$ & 1 & 71 & 71 & $6,66 \%$ & $93,33 \%$ \\
\hline $75-81$ & 1 & 78 & 78 & $6,66 \%$ & $99,99 \%$ \\
\hline Jumlah & 15 & 363 & 801 & 100 & 100 \\
\hline \multicolumn{5}{|c|}{$\begin{aligned} \text { Nilai Terendah } & =41,5 \\
\text { Nilai Tertinggi } & =78,5\end{aligned}$} & \\
\hline
\end{tabular}

Dari tabel 1 diatas, diperoleh data yang menunjukan nilai rata-rata kelas sebesar 50,37 . Dengan nilai terendah adalah 41,5 dan nilai tertinggi adalah 78,5 . Adapun ketuntasan klasikal pada kegiatan pratindakan ini hanya sebesar $13,33 \%$ atau 2 siswa dari 15 siswa yang sudah tuntas $\mathrm{KKM}$ dan masuk kategori terampil, sedangkan $86,66 \%$ atau 13 siswa belum tuntas $\mathrm{KKM}$ atau belum terampil, sehingga dapat disimpulkan bahwa keterampilan menyimak cerita pendek siswa kelas V SD Negeri 
Sigit II masih rendah. Sehingga peneliti mengajak siswa untuk menerapkan Mind Mapping saat menyimak cerita pendek. Peneliti telah rerancang langhak-langkah penerapan Mind Mapping ini yang disesuaikan dengan beberapa pertimbangan. Adapun langkah-langkah penerapannya adalah sebagai berikut: 1) memperkenalkan tentang Mind Mapping terlebih dahulu kepada siswa; 2) menjelaskan cara pembuatannya; 3) selanjutnya guru mengajak dan mengarahkan siswa untuk mengonsep terlebih dahulu Mind Mapping yang akan digunakan untuk menyimak. Hal ini bertujuan untuk menghindari agar siswa tidak sibuk menghias Mind Mapping mereka, dengan kata lain untuk memfokuskan siswa pada kegiatan menyimak.; 4) guru mulai melisankan suatu cerita atau bercerita, saat guru bercerita siswa mulai mengisi Mind Mapping mereka. Jadi selama menyimak, siswa akan mengisi Mind Mapping mereka. Hal ini selaras dengan pernyataan Abidin (2013: 107) bahwa selama tahap menyimak siswa sebaiknya mengisi peta konsep. Hal ini berguna untuk meningkatkan daya ingat dan daya konsentrasi. Namun pada penelitian ini, peneliti menerapkan peta pikiran (Mind map) bukan peta konsepPada tahap ini siswa harus berkonsentrasi menyimak cerita, karena siswa harus mengisi Mind Mapping mereka berdasarkan cerita yang mereka simak. Jika mereka tidak menyimak dengan baik, maka tentunya Mind Mapping siswa tidak akan terisi. Setelah selesai menyimak siswa akan diberikan kesempatan untuk menelaah Mind Mapping yang telah mereka buat. Setelah diterapkannya Mind Mapping pada siklus I hasil belajar siswa mengalami peningkatan. Berikut adalah tabel distribusi frekuensi nilai menyimak cerita pendek siswa siklus I:

Tabel 2. Distribusi frekuensi nilai menyimak cerita pendek siklus I

\begin{tabular}{|c|c|c|c|c|c|}
\hline \multirow[t]{2}{*}{ Interval Nilai } & \multirow{2}{*}{$\begin{array}{l}\text { Frekuensi } \\
\text { (fi) }\end{array}$} & \multirow{2}{*}{$\begin{array}{c}\text { Nilai } \\
\text { Tengah } \\
(x i)\end{array}$} & \multirow{2}{*}{ fi.xi } & \multicolumn{2}{|c|}{ Persentase } \\
\hline & & & & Relatif & Kumulatif \\
\hline $45-50$ & 1 & 42.5 & 86 & 6,66 & 6.66 \\
\hline $51-56$ & 2 & 53.5 & 107 & 13,33 & 19.99 \\
\hline $57-62$ & 3 & 59.5 & 178,5 & 20 & 39.99 \\
\hline $63-68$ & 1 & 65.5 & 65,5 & 6,66 & 46.65 \\
\hline $69-74$ & 7 & 71.5 & 500,5 & 46,66 & 93.31 \\
\hline $75-80$ & 1 & 77.5 & 77,5 & 6,66 & 99.97 \\
\hline Jumlah & 15 & 370 & 1015 & 100 & 100 \\
\hline \multicolumn{6}{|c|}{$\begin{array}{c}\text { Nilai Rata-rata Kelas }=978,5: 15=65 \\
\text { Ketuntasan klasikal }=53,33 \% \\
\text { Nilai Terendah }=45 \\
\text { Nilai Tertinggi }=77\end{array}$} \\
\hline
\end{tabular}

Dari tabel 2 di atas, dapat dilihat bahwa nilai rata-rata kelas adalah 65. Dengan nilai terendah 45 dan nilai tertinggi 77 . Nilai siklus I didominasi pada interval 69-74 yaitu sebanyak $46,66 \%$ atau sebanyak 7 siswa. Jumlah siswa yang mendapatkan nilai sama dengan dan lebih dari 69-74 adalah 8 siswa. Sedangkan ketuntasan klasikalnya adalah 53,33\% atau sebanyak 8 siswa sudah masuk pada kategori terampil, hal ini menandakan adanya peningkatan nilai keterampilan menyimak cerita pendek siswa dari pratindakan. Karena indikator kinerja dalam penelitian ini yaitu $80 \%$ siswa terampil menyimak cerita pendek belum tercapai, maka peneliti melaksanakan siklus II dan hasilnya indikator kinerja tercapai, berikut adalah distribusi ftrekuensi nilai keterampilan menyimak cerita pendek siklus II: 
Tabel 3. Distribusi frekuensi nilai menyimak cerita pendek siklus II

\begin{tabular}{|c|c|c|c|c|c|}
\hline \multirow[t]{2}{*}{ Interval Nilai } & \multirow{2}{*}{$\begin{array}{c}\text { Frekuen } \\
\text { si (fi) }\end{array}$} & \multirow{2}{*}{$\begin{array}{c}\text { Nilai } \\
\text { Tengah } \\
(x i)\end{array}$} & \multirow{2}{*}{ fi.xi } & \multicolumn{2}{|c|}{ Persentase } \\
\hline & & & & Relatif & Kumulatif \\
\hline $65-70$ & 2 & 67,5 & 135 & 13,33 & 13,33 \\
\hline $71-76$ & 3 & 73,5 & 220,5 & 20 & 33,33 \\
\hline $77-82$ & 5 & 79,5 & 397,5 & 33,33 & 66,66 \\
\hline $83-88$ & 3 & 85,5 & 256,5 & 20 & 86,66 \\
\hline $89-94$ & 2 & 91,5 & 183 & 13,33 & 99,99 \\
\hline Jumlah & 15 & 397.5 & 1192,5 & 100 & 100 \\
\hline \multicolumn{6}{|c|}{ 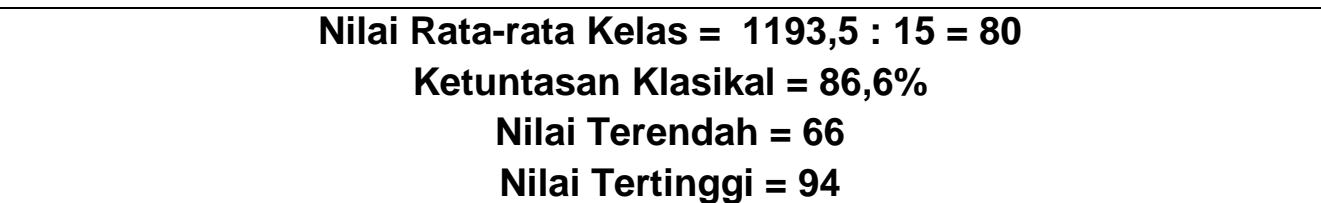 } \\
\hline
\end{tabular}

Berdasarkan tabel 3 di atas, dapat diketahui bahwa pada siklus II ini nilai rata-rata menyimak cerita siswa adalah 80 dengan nilai tertinggi 94 dan nilai terendah 66 . Serta ketuntasan klasikalnya adalah $86,6 \%$ atau 13 siswa dari 15 siswa telah masuk pada kategori terampil. Hal ini juga menunjukan adanya peningkatan keterampilan menyimak siswa sebanyak $33,3 \%$ dari siklus I. Hal ini juga menandakan bahwa indikator kinerja penelitian ini telah tercapai sehingga siklus berhenti pada siklus II.

\section{SIMPULAN}

Berdasarkan hasil penelitian tindakan kelas yang telah dilaksanakan selama dua siklus dapat disimpulkan bahwa penerapan Mind Mapping dapat meningkatkan keterampilan menyimak cerita pendek siswa kelas V SD Negeri Sigit II tahun ajaran 2017/2018. Serta langkah-langkah penerapan Mind Mapping yang tepat dapat dapat meningkatkan keterampilan menyimak cerita pendek siswa kelas V SD Negeri Sigit II tahun ajaran 2017/2018. Implikasi dari penelitian ini yaitu: 1) meningkatnya keterampilan menyimak cerita pendek siswa; 2) menambah wawasan siswa serta guru tentang penerapan Mind Mapping untuk menyimak cerita; 3) guru mendapatkan tambahan referensi untuk menciptakan pembelajran yang aktif dan inovatif.

\section{DAFTAR PUSTAKA}

Abidin,Yunus. (2013). Pembelajaran Bahasa Berbasis Pendidikan Karakter. Bandung: PT Refika Aditama.

Busan, Toni. (2010). Buku Pintar Mind Map. Jakarta: PT Gramedia Pustaka Utama Edward, Caroline. (2009). Mind Mapping untuk Anak Sehat dan Cerdas. Yogyakarta: Sakti.

Ghazali, Syukur. (2013). Pembelajaran Keterampilan Berbahasa Dengan Pendekatan Komunikatif-interaktif. Bandung: PT Refika Aditama. 